\title{
El reino de los Germanóvich: consideraciones sobre la cuestión gay presente en El gato de sí mismo de Uriel Quesada
}

\author{
José Pablo Rojas González²
}

Recepción: 26 de febrero de 2014 / Aprobación: 30 de abril de 2014

\section{Resumen}

Este trabajo buscará explicar -a partir de la novela de Uriel Quesada, El gato de sí mismo- los principios estructuradores de las vidas gays y, sobre todo, las formas en las que Germán Germanóvich -el narrador-protagonista de dicho texto- plantea, a través de su autobiografía, una resistencia a la sujeción. Para ello, se utilizarán los aportes de Didier Eribon, tomados de su libro Reflexiones sobre la cuestión gay. Se comprobará, además, cómo los procesos de "resubjetivación" son una forma de huida contra la sojuzgación que opera en las normas sociales heterocentristas. Finalmente, se demostrará que lo relevante, para el caso del protagonista de esta novela, consiste en abrir espacios de resistencia, pero sobre todo en imaginar posibilidades de reinvención de sí mismo, al margen de la norma heterosexual.

\section{Palabras clave}

El gato de sí mismo; literatura gay; sujeción; resubjetivación

\section{Abstract}

This article seeks to explain -from Uriel Quesada's novel El gato de sí mismo- the structuring principles of gay lives; more specifically, the ways by which Germán Germanóvich -the narrator and protagonist of this story- resists against subjection through his autobiography. In order to achieve this goal, the contributions of Didier Eribon in his book Insult and the Making of the Gay Self are used as theoretical framework. It is also demonstrated how the processes of "resubjectification" are a way to escape from the social norms' of heterocentric subjugation. Finally, it is shown that what is relevant for the protagonist of this novel is to create spaces of resistance and, above all, to imagine possibilities of reinventing himself out of heterosexual norms.

$1 \quad$ Este artículo es un producto derivado del tercer capítulo de la tesis de maestría en Literatura Latinoamericana titulada El gato de sí mismo, de Uriel Quesada: Novela de la travestización literaria (Rojas, 2012). Esta tesis se defendió el 30 de marzo de 2012, en la Universidad de Costa Rica.

2 Costarricense. Máster en Literatura Latinoamericana por la Universidad de Costa Rica (UCR). Profesor de la Sección de Comunicación y Lenguaje de la Escuela de Estudios Generales, UCR. Correo electrónico: josepablo.rojasgonzalez@ucr.ac.cr 


\section{Keywords}

El gato de sí mismo; gay literature; subjection; resubjectivation

\section{Resumo}

Este artigo procurará explicar, a partir do romance de Uriel Quesada, El gato de sí mismo, os princípios estruturantes da vida gay e, especialmente, as maneiras pelas quais Germán Germanóvich, o narrador-protagonista do texto, levanta através de sua autobiografia, a resistência à fixação. Para fazer isso, as contribuições de Didier Eribon, tirada do livro, Reflexões sobre a questão gay, serám usadas. Ele irá verificar como os processos de "resubjetivação" são uma forma de escape contra a subjugação heterocentrista que operam as normas sociais. Finalmente, vamos mostrar que o que importa, no caso do protagonista deste romance, é abrir espaços de resistência, mas, acima de tudo, imaginar as possibilidades de reinventar-se, fora da norma heterossexual.

\section{Palavras chave}

El gato de sí mismo; literatura gay; sujeição; resubjetivação

\section{A manera de introducción: reflexiones sobre la cuestión gay}

Resist much, obey little. Walt Whitman

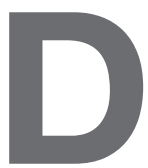
idier Eribon, en el prefacio de su libro Reflexiones sobre la cuestión gay, explica que el "sujeto" es producido por el orden social: "un 'sujeto' es siempre producido en y por la 'subordinación' a un orden, a reglas, normas, leyes... Esto es cierto para todos los 'sujetos'. Ser 'sujeto' y estar subordinado a un sistema de impedimentos son una sola y misma cosa. Pero aún es más cierto en el caso de 'sujetos' a los que el orden social y sexual asigna un lugar 'inferiorizado' como ocurre con los homosexuales [cursivas añadidas] (Eribon, 2001, p. 16).

A partir de lo anterior, este autor se propone analizar el proceso específico de "sujeción" de los gays ${ }^{3}$. Eribon parte, para ello, de la injuria ${ }^{4}$, con el fin de

3 Como lo hace Didier Eribon, se emplea la palabra "gay" por el simple motivo de que es la palabra con la que actualmente se designa a las personas "homosexuales". Afirma el autor francés: "Elegir la palabra 'gay' es reconocer la legitimidad y la necesidad del movimiento de afirmación de uno mismo que la ha instituido" (Eribon, 2011, p. 33).

4 "En el principio hay la injuria", así inicia Eribon su análisis sobre este acto del lenguaje que -como una de sus consecuencias- moldea las relaciones de "uno" con los demás y con el mundo. La injuria perfila, según este autor, la personalidad, la subjetividad, el "ser" mismo del individuo, "la injuria 
explicar la manera en la que los gays están "sujetos" por el orden sexual. Sin embargo, el teórico francés no solo busca explicar este proceso, sino que también trata de entender las formas en las que los gays han resistido dicha sujeción, a través de la "subjetivación"5 o "resubjetivación"6.

Como se verá, los procesos de "resubjetivación" son fundamentales para analizar no solo la figura del protagonista de la novela de Quesada, sino también su narración de vida7, una narración cargada de ciertos elementos del "humor de loca", del camp ${ }^{8}$. Este trabajo, precisamente, tiene como objetivo demostrar las formas en las que Germán, con su narración, busca constantemente su resubjetivación; es decir, se pretende acá evidenciar los medios que tiene este gay para acabar con los discursos que lo sujetan y poder construir su propia "identidad”, desde sí y para sí.

Dicho lo anterior, habría entonces que ligar la "resubjetivación" (que no es sino un trabajo creativo sobre el "ser" mismo) con la importancia del elogio del selffashioning de Oscar Wilde; es decir, "la idea de que podemos crearnos a nosotros mismos y hacer de nuestra vida una obra de arte" (Eribon, 2001, p. 20). Esta

es un enunciado performativo: su función es producir efectos y, en especial, instituir o perpetuar la separación entre los 'normales' y aquellos a los que Goffman llama los 'estigmatizados', e inculcar esta grieta en la cabeza de los individuos. La injuria me dice lo que soy en la misma medida en que me hace ser lo que soy" (Eribon, 2001, p. 31).

5 La "resubjetivación" o "subjetivación" se refiere a "la posibilidad de recrear la identidad personal a partir de la identidad asignada... Se trata siempre de una reapropiación o, por emplear la expresión de Judith Butler, de una 'resignificación'” (Eribon, 2001, p. 18).

6 Siguiendo a Eribon, se podría plantear la subjetividad como el resultado del proceso de subjetivación. Así, desde esta perspectiva, subjetividad e identidad son términos íntimamente ligados, aunque, evidentemente, no son sinónimos. Podríamos organizar estos conceptos de la siguiente manera: Sujeto $\approx$ Identidad asignada $\neq$ Subjetividad $\approx$ Identidad recreada o personal. Claramente, la subjetividad se liga a lo que Eribon llama "el acto de libertad por excelencia". La identidad no es, entonces, inmutable, de ahí que sea incluso posible entenderla de diferente forma, según se haya dado o no el proceso de subjetivación, como se ve en la fórmula expuesta. Afirma Eribon: "la injuria en la vida cotidiana de los homosexuales de hoy y la estructura del orden sexual de la que es síntoma son factores determinantes del 'sojuzgamiento' (la subjetividad producida como sujeción), pero también, y al mismo tiempo, de la posible y necesaria subjetivación (la reinvención de la subjetividad como conciencia autónoma)" (Eribon, 2001, p. 199).

7 El argumento de esta novela es, aparentemente, muy sencillo: la novela se constituye como un relato autobiográfico - cargado de elementos fantásticos - que cuenta el rechazo, la separación familiar, la huída y el reencuentro de un gay, Germán Đ El Gado, con su padre, Don Luis Dieciséis (un reencuentro que terminará, de nuevo, en separación). Al lado de esta historia, se presenta la historia de amor del protagonista e íñigo y la historia del descubrimiento del "asunto" que su padre escondía: una hija bastarda.

8 Afirma Eribon: "el humor de 'loca' y el camp pueden describirse, ciertamente, como otras tantas estrategias de resistencia o de reapropiación de la acusación de afeminamiento, pero expresan sobre todo la creatividad, la inventiva de una cultura minoritaria, y asimismo la manera en que dicha cultura es, gracias a esta forma de ironía, la mejor crítica de sí misma y de las otras" [cursivas añadidas] (Eribon, 2001, p. 130). El camp, según lo planteado, es tanto una estética, como una visión de mundo. Lauren Alexandra Ross lo explica en los siguientes términos: "I adhere to the idea that the ultimate point enacted by camp is its ability to constantly avoid fixity, as camp works through a "radical semiotic destabilization, in which object and subject of discourse collapse onto each other" (Ross, 2010, p. 3). Mark Booth, por su parte, indica que "to be camp is to present oneself as being committed to the marginal with a commitment greater than the marginal merits" (Booth, 1983, p. 69). 
idea es la que lleva Eribon a Foucault, quien insistió en la relevancia de forjarse a sí mismo. Eribon, en efecto, deconstruye el pensamiento de Foucault, pero para resaltar su esfuerzo a la hora de inventar gestos de resistencia. Este artículo, entonces, también procura, a partir de lo planteado en Reflexiones sobre la cuestión gay, restituir el movimiento que lleva de la sujeción a la reinvención de uno mismo. Es decir, de la subjetividad moldeada por el orden social a la subjetividad elegida (Eribon, 2001, p. 22) ${ }^{9}$.

Es importante aclarar que Eribon, para sus consideraciones, utiliza tanto los cuadros estadísticos de los sociólogos como los relatos contenidos en las autobiografías de los gays. En este sentido, Eribon afirma que no existe una realidad única de la homosexualidad; sin embargo, sí es posible encontrar los "núcleos duros" (Amoretti, 2003, p. 23) en la constitución de la "identidad" gay, una "identidad", como se verá con la novela de Quesada, "irrealizable", en tanto solo puede entenderse como un proceso constante de construcción e invención de sí mismo.

Esta afirmación sobre la "identidad" gay, sin lugar a dudas, es cierta para todos los sujetos; sin embargo, como se verá, es todavía más patente en sujetos como el gay, compelidos a actuar lo que no son, a enmascararse constantemente, a controlar de forma muy estricta sus gestos y palabras. Más adelante, se expondrá cómo el proceso de sujeción del gay permite que se exacerbe este carácter "irrealizable" de la "identidad" gay¹0.

Es importante iniciar con los planteamientos en torno a los elementos constitutivos del "sujeto" gay, para, luego -a la luz de dichos elementos- poder comprender de manera más orgánica la novela costarricense seleccionada. Antes se mencionó a la injuria como uno de esos elementos, tal vez el más importante, sobre todo en la medida en que activa el siguiente elemento: la huida. Las vidas gays son -explica Eribon- vidas diferidas, que solo inician en el momento en el que el "sujeto" se reinventa al salir de su silencio. Pero, como se está señalando, es gracias a las heridas experimentadas durante la "vida vivida por delegación" que surgen "las energías con las que los gays se crean o recrean personalidades" (Eribon, 2001, p. 49). Esta es, evidentemente, la energía creativa producto de la huida: el gay debe huir del

$9 \quad$ Este movimiento, evidentemente, no se puede entender como exclusivo de los gays. Es claro que las afirmaciones de Eribon, aunque muchas veces se concentran en el hombre gay, se pueden aplicar a la mayoría (si no a todos) los sujetos subalternos. En este sentido, es necesario resaltar que este teórico busca, con su trabajo, presentar un "conjunto articulado de reflexiones", que puede estar incompleto y -siempre- necesitado de nuevas ideas.

10 Afirma Eribon: "pero, ¿no se distingue la vida de los gays por un «acoso moral» permanente, directo o indirecto, un acoso presente en todas las situaciones de su existencia, un acoso social? Y la personalidad que construyen, la identidad que moldean, ¿no están determinadas por las consecuencias psicológicas de esta posición social de "acosados" en la vida cotidiana (por la injuria, la burla, la agresión, la hostilidad ambiental)? Se entiende que uno de los principios estructuradores de las subjetividades gays y lesbianas consista en buscar los medios para huir del ultraje y la violencia, que con frecuencia recurran a disimular lo que son o a emigrar hacia climas más benignos" (Eribon, 2001, p. 33). 
patrón hetero-normativo, de la violencia, de la "interpelación heterosexual", de la "melancolía". Huir es, para el sujeto gay, nada más y nada menos que un "elegirse a sí mismo".

Respecto a la melancolía (otro elemento constitutivo del "sujeto" gay), el estudioso francés la entiende como un "trabajo de duelo que nunca termina e imposible de cumplir, que marca, según Freud, el proceso de formación del 'yo' a través de las identificaciones rechazadas” (Eribon, 2001, p. 57). Esta "melancolía" gay, entonces, se explica a partir de las múltiples rupturas que el individuo tiene con la estructura familiar y la inserción social. Afirma Eribon:

La "melancolía" procedería del duelo imposible de cumplir o terminar de lo que la homosexualidad hace perder a los homosexuales, a saber, las formas de vida de los heterosexuales, a la vez rechazados y repudiados (o a los que estás obligado a rechazar porque ellos te rechazan), pero cuyo modelo de integración social continúa obsesionando el inconsciente y las aspiraciones de numerosos gays y lesbianas. Bergson dice que la vida de un individuo está obsesionada por las elecciones que no ha hecho (Eribon, 2001, p. 59).

Lo anterior explica que sea tan importante para el "sujeto" gay aspirar a un modo de vida que le permita superar no solo una "posición miserable" (que le resulta insoportable) sino, también, su expresión psicológica: la "melancolía". Evidentemente, dicha "posición miserable" solo se puede explicar a partir del primer elemento mencionado, a partir de la injuria, y su expresión más clara la encontramos en la cuestión del "clóset".

En el apartado "Decir y no decir", Eribon detalla algunos puntos más sobre la injuria, para, luego, centrarse en el "clóset". Este estudioso explica que el miedo de ser descubierto puede tener consecuencias en los gays y que, en efecto, así es: el miedo a la injuria es el que permite que muchos "sujetos" vivan en el espacio del clóset (les guste o no). El miedo no es más que uno de los resultados de la injuria, él es fruto de ese "estigma" invisible con el que carga el gay, quien se ve, inevitablemente, obligado a disociarse:

Los homosexuales se ven a menudo inducidos a desarrollar repertorios de comportamientos a los que recurren en función de los públicos diferentes que afrontan, pasando de un tipo de gestualidad o de actitud a otro según las exigencias de la situación: por ejemplo, los mismos que se hacen las "locas" ante un pequeño grupo de otros gays limitarán su vocabulario, sus expresiones y sus entonaciones a la más estricta normalidad en el ambiente profesional (Eribon, 2001, p. 75).

Con lo anterior, se entiende la relevancia del clóset, en la medida en que este espacio, que describe el "lugar (social y psicológico) en donde están escondidos los gays y las lesbianas que disimulan su homosexualidad" (Eribon, 2001, p. 73), activa -en su interacción con el exterior- un proceso constante de disociación del gay. Buena parte de la energía de este "sujeto" es producto de la tensión que se establece, precisamente, entre el decir y el no decir, 
entre el deseo de declarar y la obligación de callar, entre el mostrarse y el ocultarse, etcétera ${ }^{11}$.

Las vidas homosexuales, entonces, se caracterizan por esa tensión entre el "secreto" y la gestión diferenciada de este que, además, puede ser ya, de por sí, conocido por los demás (y que fingen ignorarlo); así, el homosexual se encuentra en un lugar inferior, sobre todo en la medida en que es objeto del discurso de los otros. La asimetría entre el gay y el heterosexual queda clara con lo dicho: la posición del gay es una "posición miserable", que se perpetúa con la permanencia en el "clóset" y con las consecuencias que este tiene en las subjetividades gays. Afirma Eribon:

Para un gay no termina nunca la necesidad de elegirse a sí mismo frente a la sociedad y la estigmatización... El coming out es una conversión. Pero aunque pueda describirse como el gesto de un "instante", el de la decisión, hay que añadir de inmediato que es preciso prorrogarla continuamente. El coming out, en el fondo, es el proyecto de toda una vida: porque siempre se plantea la cuestión de saber dónde, cuándo y ante quién es posible no ocultar lo que se es (Eribon, 2001, p. 159).

\section{Y sigue:}

La adhesión a uno mismo es sin duda más fácil para un heterosexual. Sin pretender que la vida de los heterosexuales carece de fisuras, y que son personas que viven en la adecuación consigo mismas, cabe pensar que la vida familiar, los ámbitos tan poderosamente heteronormativos de la vida profesional y, en el fondo, todo el orden sexual que insta a los comportamientos heterosexuales a sentirse legítimos y "normales", garantizan una estabilidad que da ocasión de encontrarse a uno mismo y de coincidir con los roles sociales establecidos, con identidades socialmente fijadas y aceptadas, presentadas incluso como modelos, moldeadas como la norma por y para la heterosexualidad (Eribon, 2001, p. 161).

El lenguaje sujeta, está ahí desde antes del nacimiento de los individuos esperando para apoderarse de ellos. En este sentido, la injuria es un caso particular de ese "poder constitutivo e 'insultante' del lenguaje" (Eribon, 2001, p. 85). La injuria, entonces, cumple (como elemento nuclear en la constitución del "sujeto" gay) la función de lo que Althusser llama la "interpelación"; es decir, cumple la función de un "mandato de autoridad" que asigna a alguien un lugar en un espacio social sexualizado:

El orden social y sexual cuyo vehículo es el lenguaje, y uno de cuyos síntomas más agudos es la injuria, produce al mismo tiempo el sujeto como subjetividad y como sujeción, es decir, como una persona adaptada a las reglas y a las jerarquías socialmente instituidas. La subjetividad gay es, pues, una subjetividad "inferiorizada", no solo porque encuentra la situación inferior creada para los homosexuales

11 Al respecto, explica Eribon que: "el control de la homosexualidad descansa en ese silencio impuesto y en esa disimulación forzosa, y sobre todo en el sentimiento de culpabilidad e inferioridad que no puede por menos de producir la inscripción en las conciencias individuales de la escisión entre lo que uno es y lo que puede hacer, entre lo que es y lo que puede decir" (Eribon, 2001, p. 79). 
en la sociedad, sino sobre todo porque está producida por ésta: no hay, por un lado, una subjetividad que pre-existe y, por otro, una huella social que a continuación la deformase. La subjetividad y esta huella social no son sino la misma cosa: el "sujeto" individual es producido por la interpelación, o sea, por las estructuras cognitivas y por ende sociales de las que es vector (Eribon, 2001, p. 88).

Con lo dicho, es claro que la "homosexualidad" designa tanto una clase de individuos como un conjunto de procesos de "sujeción" que -como afirma Eribon- son colectivos e individuales: cada gesto gay, cada participación en la vida gay, pone a cualquier "homosexual" en relación con los demás "homosexuales" y con toda la historia de la "homosexualidad" y de sus luchas.

La injuria se talla en lo más profundo del "ser" en el "alma" de los "sujetos" gays, a quienes, entonces, se les marca -incluso desde antes de saber ellos mismos su sexualidad- un destino cargado de un sentimiento de inseguridad, de angustia y hasta de pánico:

Esta violencia simbólica está anclada sin duda en lo que Bourdieu llama la "dominación masculina", que podríamos entender no sólo como la dominación de los hombres sobre las mujeres, sino también, más en general, como la dominación del "principio masculino" sobre el "principio femenino", y por lo tanto del hombre heterosexual (jes decir, el hombre!) sobre el homosexual (al que no se le considera hombre) en la medida en que la homosexualidad está situada en el inconsciente de nuestras sociedades en el lado de lo "femenino" (Eribon, 2001, p. 115).

Este orden es, precisamente, el que produce la "conciencia herida" con la que cargan todos los "sujetos" subalternos, una conciencia que es imperativo neutralizar, con el fin de reinventar y remodelar esa "alma" a la que se ha hecho referencia: "se trata de producir uno mismo sus propias representaciones $\mathrm{y}$, mediante ese gesto, producirse como sujeto del discurso, rechazando ser únicamente el objeto del discurso del Otro" (Eribon, 2001, p. 110). Así, las subjetividades gays, en su lucha por el desprendimiento de una conducta, una apariencia, una práctica y, finalmente, un lenguaje opresivos, deben aprender una nueva forma de hablar y nuevos modos de "[re]presentación de sí mismos":

Decidir que vas a liberar tu palabra de las trabas impuestas por el control sobre ti mismo en cada momento de tu existencia no significa solamente que opones una identidad elegida y afirmada a otra identidad impuesta y disimulada, sino que tienes que reconstruirte, encontrar los medios de hacerlo y los apoyos necesarios para conseguirlo (el trato social en el 'mundo gay' es hoy, sin ninguna duda, el más eficaz de esos medios) (Eribon, 2001, p. 142).

Decir la homosexualidad es, en este sentido, fundamental. La visibilidad es, de hecho, determinante para escapar de la "conciencia herida", del "alma" sojuzgada por la vergüenza (aprendida) de sí mismo, al tiempo que, con ella, se cancela la obligación a mantener los roles sexuales "odiosos" -la "homosexualidad"- en el ámbito privado, en el silencio. Eribon explica que, para el gay y para las lesbianas, la injuria (su poder de intimidación) establece los límites entre lo público y lo privado, por lo que para estos sujetos no 
son espacios materialmente distintos: "se trata de una estructura binaria que se reproduce de manera homóloga en todas las situaciones de la vida y en todas las situaciones sociales" (Eribon, 2001, p. 147).

Decir la homosexualidad es, pues, liberarse de la "doble vida" a la que se le ha condenado a vivir al gay. Al respecto, léase lo que apunta Eribon:

El homosexual que habla de su vida "privada" rompe la situación "normal" porque ésta se define como tal por el hecho de que, "normalmente", como se dice en el lenguaje de todos los días, la homosexualidad no es decible o, lo que no es muy distinto, no se dice a menudo. Toda palabra que consista en decir la homosexualidad sólo puede, por tanto, entenderse como una voluntad de afirmarla, de exhibirla como un gesto de provocación o un acto militante (Eribon, 2001, p. 149).

La exhibición de la homosexualidad es, entonces, una liberación ante la vergüenza, una liberación que rompe con la interpretación de "lo que no se es", para activar la performance de una nueva "identidad". El "sujeto" gay, en este sentido, se presenta con un nuevo "juego", alejado -ahora- de aquel de la discreción y de la imitación de los modelos heterosexuales, para entrar en el campo de la "teatralidad". Según el teórico francés (que aquí sigue a Judith Butler y a Eve Kosofsky Sedgwick) la "identidad" teatralizada del gay es fruto de la vergüenza, que, entonces, actúa como una fuerza transformadora ${ }^{12}$, en cuanto, claro, se dice la homosexualidad.

Todo lo anterior lleva a la dificultad de definir la "identidad" gay. Eribon, entonces, la explica en los siguientes términos:

[La "identidad" gay] es necesariamente plural, múltiple: es una identidad sin identidad o, más exactamente, una identidad sin esencia. Una identidad por crear. En efecto, no existe un "yo" en "ser", que preexistiría a lo que se ha hecho llegar a la existencia, desde el momento en que se quiere arrancar a los contenidos psicológicos impuestos por el discurso social y cultural (médico, psicoanalítico, jurídico...) sobre la homosexualidad. Por eso Henning Bech puede decir que el homosexual es un "existencialista nato", porque la existencia precede (siempre) a la esencia: la identidad gay puesto que es escogida y no ya sufrida, no es nunca un hecho dado. Pero para construirse se refiere necesariamente a modelos ya establecidos, ya visibles (en su multiplicidad), y puede decirse, en consecuencia, que se trata de "hacerse gay" no solo en el sentido de crearse como tal, sino también de hacerlo inspirándose en ejemplos ya disponibles en la sociedad y en la historia. Si hay "identidad", es una identidad personal que se crea en la relación con una identidad colectiva. Se inventa en y por medio de los "personajes sociales", los "roles" que se "interpretan" y que cobran existencia en un horizonte de recreación colectiva de la subjetividad homosexual (Eribon, 2001, p. 158).

12 Interpretar, entonces, debe entenderse, en este punto, no solo como un trabajo artístico de representación sino, también, como una forma de concebir, ordenar o expresar de un modo personal ("auténtico, en el sentido sartriano) la realidad. 
Esta larga cita es importante presentarla, en la medida en que aclara la labor personal que tiene que llevar a cabo el gay sobre sí mismo: la "identidad" gay es una "identidad irrealizable"; es decir, es un trabajo constante de decisión sobre el propio "ser"13. La "estética de sí mismo" de la que se habló antes va, precisamente, en esta línea. La "estética de sí mismo" no es otra cosa que "la toma de conciencia y la asunción a un nivel deliberado y escogido de esta estructura de inadecuación que define la vida cotidiana y la conciencia de los gays y las lesbianas" (Eribon, 2001, p. 164).

A partir de todo lo señalado, este trabajo buscará explicar no solo los principios estructuradores de las vidas gays presentes en la novela de Quesada sino, también, las formas en las que Germán Germanóvich -el narrador-protagonista- plantea, a través de su autobiografía, una resistencia a la sujeción. Como se verá, el trabajo sobre sí mismo que implica el proceso de "resubjetivación" explicado antes es, finalmente, una escogencia entre la vida y la muerte, entre la libertad y el sufrimiento.

\section{De la melancolía a la alegría (y viceversa)}

Se tomará como punto de partida para este apartado la idea de que la novela de Quesada intenta dar a los amores del mismo sexo un derecho de acceso a la expresión pública, como afirma Eribon para el caso de los discursos de Oscar Wilde:

Esta voluntad de hablar ha revestido siempre la forma de lo que Foucault llama un "discurso de réplica": se ha formulado siempre como reacción "estratégica" ante valores, normas, representaciones que la condenaban de antemano, desde luego, pero más fundamentalmente la forjaban desde el interior. La represión de la homosexualidad ha nutrido históricamente la determinación de expresarla. Pero, a la inversa, esta expresión se ha infiltrado en la mentalidad de quienes la denigraban (Eribon, 2001, p. 19).

En efecto, como se afirmó antes, esta novela se plantea como una autobiografía de un gay ( $\mathrm{y}$, entonces, la de todos los gays, quienes se releen en ella). La idea de la autobiografía, como es claro, revela en el narradorprotagonista de El gato de sí mismo su especial interés por contar su historia de vida desde sí y, principalmente, para sí, (sobre todo en la medida en que el acto mismo de escribir se configura, en dicho texto, como una re-creación). Evidentemente, este inventarse del sujeto gay se plantea como un gesto de resistencia (de huida), como una separación respecto de las normas constituidas. En la novela de Quesada, este gesto se ejemplifica con la ruptura de Germán con su padre, quien centraliza todos los discursos heteronormativos. El gato de sí mismo, con lo apuntado, se inscribiría en una historia de la

13 Este trabajo, como se afirmó antes, no es exclusivo de los gays; sin embargo, ha quedado clara, con la revisión que se ha hecho de las reflexiones de Eribon, la relevancia que adquiere esta idea para la constitución del "núcleo duro" de las subjetividades, individuales y colectivas, de estos "seres de otro mundo". 
toma de la palabra "homosexual", en tanto se intenta, como afirma Eribon, crear espacios (en este caso, literarios) de enfrentamiento a la sujeción y de reformulación de sí mismo.

Dicho lo anterior, es necesario ahora estudiar la mostración del "sujeto" gay en esta novela, con el fin de plantear su inestabilidad identitaria. Con Eribon, se ha visto la importancia de una filosofía del lenguaje que permita entender mejor el "lugar" del sujeto gay (y, consecuentemente, su necesidad de huir de cualquier espacio asignado hacia uno escogido). Entonces, la performatividad del lenguaje a la que alude el teórico francés revela el insulto como un "veredicto estructurante", como un acto de lenguaje que señala la asimetría entre los "normales" y los "raros". Así, la re-nominación (no hay que olvidar-igualmente- que la injuria es una forma de nominación) redefine al narrador-protagonista de esta novela, quien la utiliza como una forma de transformación fantástica, literaria ${ }^{14}$ :

La voz preguntó por Germán Andrés Mateo Lucano Juan Magdalena Saulo Mahatma León Fyodor Antón Josefita Tom llich Germanóvich, heredero por sucesión de la casa de los Đ El Gado, Príncipe de El Arrabal, Marqués de Las Cinco Esquinas, Amo de La Callecilla, La Lima y La Arenilla, Señor de los Bosques del Tablón y de los Rosales de Coris, Dueño absoluto de las Minas del Paso de la Muerte, consolador de la Puebla de los Pardos, efigie impresa en estampitas cuyo reverso trae oraciones muy milagrosas. La voz preguntó por el más justo, el bello, el paciente, el desprendido, el humilde caminante, el reposo de los afligidos y la inspiración de los libres, el héroe de quienes no tienen nada, la musa de los trovadores y el sueño feliz de todos los súbditos de la Corona. "Sí", contesté aún con desconfianza, "este es Germán” (Quesada, 2005, p. 245).

El trabajo de renominación de Germán, claramente, tiene que ver con la reapropiación de la que se ha hablado antes. Sin embargo, para alcanzar esta transformación, Germán Germanóvich ha tenido antes que pasar por esa toma de conciencia de "uno" como un "otro" que los demás transforman en "objeto"; es decir, Germán ha tenido que sufrir antes la violencia que implica que otros le "pongan nombres". Esta agresión se representa, en el texto, en la figura del padre, como se indicó antes. La palabra de don Luis Dieciséis es entonces, para Germán, apresamiento y desposesión, de ahí la trascendencia que para él adquiere poner en entredicho el "decir" de don Luis y, con el, el de los discursos de poder que buscan subyugarlo:

Con mucho trabajo pude oír la diatriba de Su Majestad. Sospeché que simplemente repetía un discurso preparado por sus asesores, el príncipe Alberto el

14 La fantasía es el detonante del trabajo artístico-literario de Germán Đ El Gado. Desde el inicio de la novela, el narrador-protagonista se presenta como un sujeto variable, un sujeto que concibe su conocimiento de sí y de su mundo como una imaginación. Así, su narración es, en realidad, un decirse, que lo lleva a un juego de vestiduras y, entonces, a una parodia respecto de sí mismo y de su contexto. La fantasía, en la narración de Germán, además, desestabiliza, señala una suerte de desequilibro dentro de la estructura del texto y hasta su propia configuración. Esta forma de contar(se) no hace sino potenciar la interpretación; es una manera de atentar contra lo definido, contra lo concreto, contra -incluso- "lo racional". 
primero de ellos: Queridos míos, hablemos de la vergüenza como fuerza motora de la vida... Hijitos, os lego mi receta para cocer supervivencia: enterraos en vida, negad el afecto, deciros que no hay algo ardiente en vuestro corazón, entrad al molde aunque os cause un dolor más prolongado que la eternidad... Sabias son mis palabras: dejaos formar por la decencia o sucumbid en vuestra rebeldía [cursivas del original] (Quesada, 2005, p. 62).

Con lo dicho, es posible, entonces, plantear la renominación como otra forma de huida que Germán utiliza en su reconfiguración: un nuevo nombre propio es, para este héroe, una nueva vida posible, un bautismo desde sí mismo. La renominación es, pues, uno de los elementos más relevantes en la reconfiguración de las subjetividades gays, y es, en sí, una de las formas más efectivas que se tienen para abandonar los "lugares asignados". Este concepto no debe, sin embargo, entenderse simple y llanamente como un cambio de nombre. Es, más bien un cambio en la forma en la cual el sujeto se ve a sí mismo, y este cambio no es sino consecuencia de ese proceso de escape inherente a toda labor de resignificación:

Me digo: "aparece la Bella Durmiente reinstalada en su trono. Todas las brujas están muertas, las hadas madrinas posan discretas a un lado, el pueblo me adora a prudente distancia. Mi príncipe de labios carnosos y encarnados de puro deseo, aguarda para llevarme muy lejos o quizás un poco más allá, de nuevo al bosque, para desahogarnos rapidito de tantísima urgencia y amor pospuesto". Me digo: "la Niña cae dentro del árbol mágico con un vértigo que primero le hace cosquillas en el bajo vientre y después se transforma en un lento, suave flotar. La falda se abre atenuando la caída, una brisa húmeda se mete entre mis piernas y me doy cuenta que los abismos son también placenteros [cursivas añadidas] (Quesada, 2005, p. 14).

Eribon explica la insistencia de la huida en los gays en relación con el espacio (una huida hacia lugares más benévolos), pero también en relación con el acoso (una huida de la experiencia del insulto). Claramente, se huye, en El gato de sí mismo, de la opresión, una opresión que puede aparecer con muchos rostros y de muchas formas, y que en esta novela se revela, hay que repetir, en la violencia discursiva del padre. Don Luis es, en efecto, la figura que reafirma constantemente el "deber ser" en la actuación y en la organización de conductas adaptadas. Es decir, la palabra del "rey" instituye la norma y salirse de ella tiene, evidentemente, consecuencias muy dolorosas, tan dolorosas como la separación familiar y el (auto)exilio.

Sin embargo, como lo señala Germán en su historia de vida, el exilio es también un movimiento hacia la libertad (una "dolorosa libertad", como él mismo define su viaje lejos de la ciudad del padre, lejos de Cartago), pues, para el sujeto gay, el exilio es otra forma de escape, un escape obligado, pero -igualmente- acogido: "No esperes recompensa en Versalles, I sin su horrible existencia / nunca hubieras buscado camino. Cuando encuentres Versalles / tal y como lo dejaste / comprenderás por fin / el significado de los falsos viajes" [cursivas del original, subrayado añadido] (Quesada, 2005, p. 336). 
"La huida a la ciudad" de la que habla Eribon ${ }^{15}$ en sus reflexiones se representa -en esta novela costarricense- en el paso del protagonista de Cartago a Santa Cruz. Santa Cruz es, en efecto, esa "ciudad cosmopolita" (como la llama el protagonista), en donde un sujeto como él puede huir de ese "acoso social" constante que, según este estudioso, distingue la vida de los gays. Precisamente, la evidencia de este acoso (por la burla, la injuria, la agresión, la hostilidad ambiental, etcétera) permite entender ese "escape" al que se ha hecho referencia en relación con Germán Germanóvich: buscar los medios (discursivos, literarios) para huir del ultraje y la violencia es uno de los principios estructuradores de la narración de la biografía de este gay.

La vida de Germán, en este sentido, ha mirado desde siempre hacia un lugar diametralmente opuesto a la casa de su padre. Germán es, por su "anormalidad", compelido a abandonar Cartago, el lugar donde nació y pasó su infancia. Este abandono se da, claramente, en ambos sentidos, pero lo más importante de este es que siempre se dirige hacia la ciudad. El término 'ciudad' no solo debe entenderse en su sentido directo sino, más importante aún, en su sentido metafórico. La ciudad, como se señala en uno de los epígrafes que abren la novela (parte de un poema de Constantino Kavafis), no es solo un lugar en el que se vive sino, también, una forma de vida que, claro, define el "ser": "no encontrarás otra tierra, otro mar. / La ciudad te perseguirá" (Quesada, 2005, p. 9). La ciudad, a partir de dicho epígrafe, es a un tiempo refugio y cárcel. Refugio en la medida en que garantiza cierta libertad y cárcel en tanto ella implica, como se ha tratado de explicar, una huida constante hacia la reapropiación; es decir, la ciudad es libertad, pero también condena: la libertad solo es posible hallarla, como lo evidencia Germán, con la condición del escape sin descanso, un escape que -ahora en otros términos- no es sino una forma de asegurar la imposibilidad de la definición en torno a la "identidad" de este "sujeto" gay.

Respecto a la idea de la ciudad-refugio que aparece en la novela de Quesada (representada en Santa Cruz) y a su relación con Germán, es importante referir -como lo hace Eribon- el valor que, para el gay ubicado en este espacio, adquieren los círculos de amigos. La ciudad-refugio es, ante todo, una manera de escapar de la condena de no poder vivir una vida gay, es decir, alegre con otros "iguales a mí". La ciudad-refugio cancela en gran medida la disimulación continua a la que se ve obligado el gay y, con ello, activa la posibilidad que se ha señalado de volver a definir la propia subjetividad, de reinventar la "identidad" personal. Esta posibilidad, evidentemente, se da al lado de la creación

15 Como señala Erving Goffman (referido por Eribon): "[La huida a la ciudad] no se trata solamente de ir a vivir 'a otro sitio', en busca de un cierto anonimato. Se trata de una auténtica fisura en la biografía de los individuos. No es sólo un recorrido geográfico ni un medio de acceder a compañeros potenciales. Es también la posibilidad de volver a definir la propia subjetividad, de reinventar la identidad personal" (Eribon, 2001, p. 41). El recorrido del "sujeto" gay hacia la ciudad nunca es solo geográfico, también es un viaje psicológico que representa, según Eribon, la evolución de la soledad hacia la sociabilidad. De lo anterior se deduce, además, la importancia de los círculos de amigos para los gays. 
de un círculo de relaciones elegidas. Los círculos de amigos -como escribe Henning Bech (citado por Eribon) - son una de las instituciones más importantes de la vida homosexual y, solamente, dentro de este marco es posible la recreación de sí. Germán, en su narración, hace hincapié precisamente en su círculo de relaciones elegidas en Santa Cruz. Sobre todas, resalta su vínculo con Yaneri Solitari.

Tenía un amor de circunstancia. Trabajaba en un hotel-zoológico, en el que padecían encierro varias especies de aves, cerdos salvajes, venados, lascivos monos que mostraban los fondillos y las verijas a los huéspedes, periquitos que gritaban improperios. Le conocí en una degustación de cocteles organizada por una escuela de turismo. Yo me presenté con alguno de mis cuatrocientos trece nombres. Por su parte, me miró directamente a los ojos, estrechó mi mano de una forma más bien parecida a una caricia, luego dijo llamarse Yaneri (Quesada, 2005, p. 91).

Facilitar los encuentros es, lógicamente, la función principal de los círculos de amigos durante ese paso a la ciudad. Lo anterior se explica por la importancia que para el gay tiene el romper con la soledad que le ha asignado el sistema heteronormativo. Como afirma Eribon, el círculo de amigos ocupa el centro de la vida gay y el recorrido psicológico (y a menudo geográfico) del homosexual representa la evolución de la soledad hacia la sociabilidad en y mediante los lugares de encuentro (ya sean los bares o los parques). De este modo, la vida homosexual se basa en los círculos concéntricos de las amistades o en la tentativa siempre reiterada de crear redes semejantes y de trabar esas amistades (Eribon, 2001, pp. 43-44). La importancia de la ciudad y de las amistades, en El gato de sí mismo, se evidencia en la añoranza constante de Germán por Santa Cruz y sus amigos allí ubicados:

Debo pensar. Debo hacer algunas llamadas. Hablar con Abtuló, el libanés, para prometerle una versión revisada de mi historia, que ahora debe incluir una hermana desconocida, una extraña a la que no deseo tener cerca y a quien mi padre, quizás, quiso tomar como mujer. Quiero decirle a Yaneri Solitari cuánto le echo de menos, deseo preguntarle si me está esperando para cabalgar las praderas (Quesada, 2005, p. 196).

Evidentemente, la participación en una misma sexualidad estigmatizada, así como la marginación y exclusión que implica, le permite a estos personajes encontrar el fundamento para la constitución de un "mundo específico" que, como explica Eribon, se inscribe tanto en las topografías de las ciudades (Santa Cruz, en este caso), como en la personalidad de los individuos, quienes se encargan de perpetuarlo con la invención, individual y colectiva, de sí mismos. ¿Qué implica, con lo dicho, plantear la "identidad" gay en estos términos? La respuesta es clara: no subestimar la energía creativa, la fuerza de construcción, también individual y colectiva, de las subjetividades ligadas a estos procesos. Finalmente, esto entraña, como afirma el teórico francés, un escape del "destino" que se le ha señalado al gay, una ruptura total con esta noción que encarcela en la estereotopía. 
Así las cosas, no es posible hablar sobre este gay, Germán Germanóvich, sin tomar en cuenta su proceso de migración o los efectos de libertad que este produce: Germán, con su exilio, accede a un "nuevo mundo", a uno que le permite la alegría de la creatividad sobre sí mismo, lo que, además, explica su "resistencia" - desde la imaginación- a la opresión y a la marginación. E movimiento a la ciudad y la sociabilidad que ella conlleva tiene para Germán un valor emancipatorio, gracias a la posibilidad de acelerar el proceso de aceptación de sí mismo: "no sé cómo decirle a don Luis Dieciséis que la princesita renuncia de nuevo a sus privilegios. No sé si vale la pena recordarle que mi mundo es otro, que muy pocos lo conocen" (Quesada, 2005, p. 326).

En relación siempre con Germán, se podría afirmar que las heridas experimentadas a lo largo de su vida en "palacio" y durante su exilio nutren las energías con las que se re-construye. Según el teórico francés, esta energía creativa se crea en la huida y por medio de ella, de ahí la centralidad que adquiere en la narración de este personaje. Afirma Eribon:

Las vidas gays son vidas diferidas; sólo comienzan cuando el individuo se reinventa... Cuando elige dejar de sufrir y, por ejemplo, forma otra familia -compuesta por sus amigos, sus amantes, sus antiguos amantes y amigos de éstos- y reconstruye así su identidad tras haber abandonado el campo cerrado y sofocante de la heterosexualidad. Semejante huida no significa necesariamente, huelga decirlo, la ruptura total con la familia, sino más bien la necesidad de mantenerse alejado de ella y mantenerla a distancia. Antes de ese cambio, las vidas gays no son sino vidas vividas por delegación, vidas imaginadas o vidas esperadas, tan esperadas como temidas (Eribon, 2001, p. 49).

Es necesario, en este punto, referir algo al respecto de la visibilidad "homosexual" que la novela de Quesada activa a partir, como se ha dicho, de uno de sus paratextos: "anacora". Según Eribon, la visibilidad "homosexual" tiene, asimismo, una finalidad individual y colectiva: ella también implica efectos de libertad, ya que rompe con el silencio obligado, con la conminación a ocultar identidades sexuales "problemáticas". El gato de sí mismo, en este sentido, participa de lo que Eribon llama la "evolución" de la vida de los gays y las lesbianas, al indicar que lo importante es que la "homosexualidad" sea expresable y mostrable. La visibilidad permite, además, la huida y la reinvención de la que se ha hablado, al promover la salida del silencio, de la clandestinidad vergonzante, incluso en aquellos quienes gustan mantenerse en el anonimato.

Son muchos los sentimientos que sufre el gay durante su niñez y adolescencia, producidos todos por la "disonancia" sexual dentro de la familia. Eribon se refiere al sentimiento difuso de ser diferente o estar marginado, de hallarse "aparte". También refiere esa necesidad -revelada por las encuestas sociológicas- de la adhesión a modelos literarios más que a modelos familiares o sociales, porque son -afirma el teórico francés- las únicas escapatorias posibles (Eribon, 2001, p. 50). 
Germán, desde el inicio de la novela, se vincula constantemente con modelos literarios o artísticos. Este personaje se identifica con personajes de cuentos de hadas (la Bella Durmiente, la Cenicienta), de películas (Joe Buck, Errol Flynn, Edward G. Robinson, James Cagney), mujeres íconos ${ }^{16}$ (Marylin Monroe, Marlene Dietrich, Greta Garbo, Gloria Swanson), del ámbito literario (Joseph Conrad, Thomas Edward Lawrence), del arte plástico (Velázquez), de la historia de la realeza (Víctor Manuel II, Rey de Cerdeña), etcétera. A Germán, en general, le interesa la ficción. Este especial gusto se explica por el poder de la imaginación $n^{17}$. Ahora, este gusto hay que verlo como un gusto más por lo interior que por lo exterior, un gusto que, desde una ideología masculinista popular, es entendido como una actividad de "loca", una actividad "más femenina"18:

Pienso, luego pienso de nuevo, y para elaborar tanta abstracción necesito tiempo, Íñigo. Vos lo sabés: pensar ha sido mi negocio de toda la vida. Decían los antiguos griegos que ocio significa estudio. Yo agregaría saber, imaginación y viaje. Pocos me entienden como vos, querido. Hay quien tiene paciencia conmigo, quien no me comprende pero aun así me acepta, quien llama mentiras a mis verdades. Mirá que incluso Dios se pone impertinente, aprovecha cualquier oportunidad para reprocharme mi profunda pasión por el ocio [cursivas añadidas] (Quesada, 2005, p. 342).

16 En relación con el vínculo que Germán construye con mujeres íconos -como con personajes femeninos, en general-, es claro su fin: rechazar la negación de lo femenino en las representaciones de los sujetos gays. Lo anterior se entiende mejor si se toma en cuenta que, ante la acusación de afeminamiento que profieren los discursos heteronormativos, muchos "homosexuales" han buscado cancelar este ligamen que, desde la perspectiva heterocentrista, enfatiza la "condición" de "no-hombres", de "invertidos" en los gays. Germán, en este sentido, desafía la virilidad normativa y rompe con los esfuerzos (que se dan tanto en gays como en heterosexuales, hay que aclarar) por desterrar del todo la imagen "femenina". Afirma Eribon: "y no vemos por qué este juego con la feminidad debería conceptuarse como la interiorización de un impedimento en lugar de como uno de los -solo uno de ellos, pero, guste o no a los demás, innegablemente uno de ellos- rasgos característicos de la homosexualidad masculina y del modo en que a un determinado número de gays les agrada pensarse y comportarse. ¿No resurge, por el contrario, esa coacción interiorizada de la incapacidad de pensar de una forma que escaparía a esas concepciones normativas de la 'virilidad' y la 'feminidad'?" (Eribon, 2001, p. 130).

17 En efecto, el centro activo del dinamismo metafórico de El gato de sí mismo está en la dialéctica entre realidad y ficción. El juego de imaginar se da a partir de esta productiva oposición que busca conmover los fundamentos del racionalismo. El ir y venir de metáforas se intensifica en esta novela costarricense con el fin de poner en crisis el lenguaje mismo, con el fin de generar una revolución discursiva que invierta el eje interpretativo de la realidad. Al respecto, la siguiente cita de la novela de Quesada: "Rasputina se paró en la puerta de Versalles [ella estaba a la espera de don Luis Dieciséis, quien misteriosamente no había regresado a "palacio"] para otear con ojos de fiera nocturna todos los puntos cardinales. Dicen que su presencia congeló el aire, el cual cayó de las alturas arrastrando hacia palacio todos los ruidos de la ciudad y, de paso, un par de aviones, una bandada de pájaros migratorios, polen e insectos varios. Los gritos de los fruteros, los últimos retozos de los niños, aquellos comentarios sobre la vida y la muerte, varios proyectos revelados por indiscreción, proposiciones galantes, insultos, confesiones, muchísimas risas, todo vino con el aire cabizbajo hasta los oídos de la hechicera. Pero nada, entre las voces no estaba la de don Luis Dieciséis" (Quesada, 2005, p. 36).

18 Hay que aclarar que estas afirmaciones en torno a Germán (y, más ampliamente, en torno a los sujetos gays) vienen a explicar determinados fenómenos señalados por las encuestas sociológicas, las cuales, evidentemente, no abarcan el conjunto de realidades que definen la "homosexualidad" en una época o en un lugar dados. 
La noción que Germán da de "ocio" es profundamente significativa, sobre todo por el papel que este personaje le acredita a la imaginación, término que recoge en sí tanto la idea de "conocimiento" como de "viaje". ¿No es imaginar un viaje por un conocimiento-otro? Germán así lo explicita con su narración, una narración que busca diseminar este elemento para proponer una nueva lectura de la realidad.

La importancia del gusto de Germán por la imaginación está en que revela la imbricación que existe entre el sentimiento de ser "diferente" y la mirada dirigida hacia la vida "artística", muy común -como afirma Eribon- en las autobiografías de los gays. El sentimiento de ser diferente, igualmente, refiere de nuevo el valor que tienen los amigos en la "cultura" gay, en la medida en que los grupos de amigos se establecen a partir de dicha "diferencia". Los amigos se configuran, pues, como una nueva familia, y ello explica la necesidad que para muchos gays tiene el romper con el medio familiar "legítimo". Como afirma el estudioso francés, esta tarea de sustituir los vínculos construidos por los lazos "naturales" y familiares dista mucho de ser una empresa fácil: "Supone que se prosiga al mismo tiempo un trabajo de duelo, a menudo largo y doloroso, y que, como todo trabajo de duelo, -Jacques Derrida lo ha recalcado certeramente-, no se termina nunca" (Eribon, 2001, p. 57).

En El gato de sí mismo, este duelo se da a partir de la ruptura constante que hay en la relación entre Germán y su padre "traidor". Germán debe renunciar no una sino dos veces a la vida en el círculo familiar. Él, como consecuencia, acepta, integra en sí mismo, esa renuncia. Al respecto, revísese la siguiente cita de la novela:

A la nana [se refiere a Rasputina] se le tuerce el vacío del pecho de sólo pensar en el instante en que ambos hermanos nos encontremos. Sin embargo apuesta a que será más fuerte el llamado de la sangre. Sueña un encuentro de telenovela: los dos príncipes dudando un instante, luego fundiéndose en un abrazo. Planea futuros imposibles, donde estamos todos juntos en bella armonía. No menciona, por ejemplo, que Su Majestad el Rey no ha dejado de preguntar por el príncipe Alberto. La nana le ha repetido una y otra vez "aquí está Germán, vino a verlo", pero don Luis Dieciséis no le responde. Por eso la vieja prefiere soñar mientras pica cebollas y solloza, pela ajos y solloza, mezcla harina con huevos, suficiente mantequilla, una pizca de sal (Quesada, 2005, p. 333).

El apartado final de la novela aclara la existencia de una "melancolía" específicamente "homosexual" (representada en el "final" de Germán). La melancolía en Germán debe ligarse a ese trabajo de duelo que nunca termina en el gay y que lo define, como se ha visto, en su relación con la estructura familiar y la inserción social que lo rechaza. Según Eribon, la melancolía se da a partir de la pérdida de los modos de vida "naturales" y de las relaciones con los demás, a causa de una sexualidad estigmatizada. En la novela, evidentemente, esta melancolía está vinculada con la ruptura de los lazos familiares (con el padre, 
sobre todo), pero también con el sueño (¿imposible?) de una vida de familia para sí mismo, con su amado e inalcanzable Íñigo:

Subiendo la empinada pendiente que separa el reino de Cartago de sus belicosos vecinos, el carro del príncipe Alberto y mi autobús se cruzarán justo al mediodía. Mientras llega ese momento vuelvo a pensar en vos, Íñigo, la única persona a quien debo hallar aunque todos me digan que no existís. No sé dónde emprender de nuevo la búsqueda, quizás en alguna esquina de San Josesburgo llena de personas felices, borrachas y satisfechas tras los festejos en honor al príncipe Alberto. El poco dinero en mi bolsillo determinará las posibilidades de viaje. Pero ahora sí voy a encontrarte, Íñigo, te lo prometo (Quesada, 2005, p. 341).

La melancolía de Germán revela su mayor "sufrimiento". Pierre Bourdieu ha puesto en evidencia, en su trabajo titulado La miseria del mundo, cómo el sufrimiento está asociado con las "posiciones" en el espacio específico en el que se vive. Así, la "miseria de posición" de Germán se explica por el "lugar" que este hijo ocupa en la casa de su padre, en oposición al "lugar" que ocupa su hermano Alberto. La novela de Quesada, como se puede colegir, pasa esta "miseria" y este "sufrimiento" del silencio (en el que generalmente se mantienen) a la palabra. Lo anterior ratifica, asimismo, la importancia señalada por mostrar la vida gay y, más significativo aún, por escapar -incluso con el suicidio- de dicho "malestar". ¿No es el "suicidio" la última forma de escape que Germán encuentra ante un acoso constante e irremediable? ¿No trata Germán, acaso, de concluir con su "sufrimiento", marcado por esas heridas de la infancia y de la adolescencia que relata en su autobiografía?

Como es claro, la determinación de Germán es siempre buscar las "salidas" posibles para tratar de eludir el "sufrimiento". Sartre, en su trabajo Saint Genet (referido por Eribon), habla de la "homosexualidad" misma como de una "salida". Eribon toma esta idea y la entiende como la elección que el "homosexual" hace con el fin de superar tanto una "miseria de posición", que le resulta insoportable, como la "melancolía", que no es sino su expresión psicológica. El "suicidio" para Germán, en este sentido, no es más que su última escapatoria:

Sigo echando cosas en la maletita de cartón. Al mismo tiempo me arrodillo en los templos rogándole a Dios unas palabras. Silencio. Dios ha cerrado los ojos y la boca como lo hizo en su momento don Luis Dieciséis. Ninguna figura divina mira a tierra, su atención se concentra en el más allá. A ese mismo lugar debo marcharme, ahora que la casa Đ El Gado presume de poder hallarme con facilidad en Santa Cruz, o en cualquier otra esquina del reino (Quesada, 2005, p. 338).

Germán decide, pues, sobre su vida y, finalmente, sobre su muerte. Así lo demuestra con su decirse a lo largo de la narración. Ya se ha afirmado antes la importancia que para los gays tiene el volverse sujeto de su propio discurso y, con ello, dejar de ser objeto del discurso del otro. La narración de Germán quiere, precisamente, romper con los discursos de todas aquellas instituciones que buscan ocultarlo y callarlo: la iglesia, la familia, la escuela, los medios de comunicación, el derecho, el deporte, el psicoanálisis y la psiquiatría, los órganos 
conservadores o tradicionales, entre otros. De este modo, la cuestión del decir es crucial para el protagonista; su narración, en este sentido, privilegia la "indiscreción", quiebra el "no querer saber" del heterosexual (según lo explica Eve Kosofsky Sedgwick), se regodea en el exceso, en la provocación"19.

La visibilidad que Germán promueve con su narración es, asimismo, una manera de asumir y reivindicar la identidad estigmatizada por la injuria, es una forma de neutralización de la violencia del insulto, insulto que, en su caso, es proferido por la boca paterna, como se ha afirmado repetidamente. Eribon explica la "visibilidad" como "una superficie reflectante donde rebota la afrenta y queda destruida, siquiera parcialmente, su terrible eficacia" (Eribon, 2001, p. 97). Lo anterior, evidentemente, también lleva a la centralidad que, para el caso de Germán (y en general, para todos los gays), tiene la labor sobre sí mismo, la cual no es sino una ruptura de los efectos que, sobre la conciencia (sobre el "alma"), producen las injurias. Afirma Eribon: "por tanto, hay que reinventar y remodelar esa 'alma'. Y este proceso no es ciertamente posible en la 'discreción', pues esta obligación o esta voluntad de ser discretos, de disimularse, no son más que productos del alma sojuzgada, inferiorizada y consciente de su inferiorización" (Eribon, 2001, p. 98).

Con lo anterior, las “indiscretas” transformaciones de Germán, evidenciadas a lo largo de la novela, no solo lo tocan a él, también implican una transformación de su mundo. Así, toda su "obra" se constituye como un puro desplazamiento, como una acción que, finalmente, trata de contrarrestar la renuncia y el silencio al que es conminado el gay: “'es suficiente, Germán', bramó Su Majestad cuando el silencio se asomó a mirar el espectáculo de la hoguera. La voz del rey descendió atronadora desde el cielo de la cocina. 'Te hice muchas advertencias, creí que ibas a corregirte, pero seguís en boca de toda la ciudad, avergonzándonos a tu hermano y a mí'” (Quesada, 2005, p. 61).

Recuperar, entonces, la autonomía personal y convertirse en un individuo de pleno derecho implica, para el caso de Germán, un trabajo de reconstrucción de su imagen, de su "ser". No extraña, en este sentido, que Germán ofrezca la inestabilidad en torno a sí mismo como su rasgo más característico, una inestabilidad que no acaba ni con su muerte. Lo anterior, evidentemente, tiene como fin escapar a la violencia simbólica ejercida por la representación dominante en torno a los gays. El "Epílogo y rebobinado" de la novela aclara lo

19 No extrañaría, con lo dicho, que alguna persona califique la novela de Quesada como un texto "insoportable", "inaguantable", sobre todo en relación con esa insistencia por la afirmación de la cuestión gay: El gato de sí mismo obliga al heterosexual que lo lee a pensarse como tal, ya que, como expone Eribon, el heterosexual no tiene, sino hasta que sufre estos "encuentros", que plantearse cuestión alguna sobre su "identidad" ni sobre el orden social que lo ha instituido: "por eso se indigna cuando sufre la amenaza de perderlo [se refiere al privilegio absoluto que el sistema heteronormativo le da al heterosexual], aunque sea parcialmente, y pide a los gays que reasuman la 'discreción', o sea, que le permitan recobrar la paz de sus certezas, el confort de su normalidad que descansaba en el silencio de los demás" (Eribon, 2001, p. 83). 
dicho, en la medida en que esta parte final de la novela se entiende como un borrar (en sus cuatro acepciones ${ }^{20}$ ) y un volver a empezar:

Lástima que debo irme con hambre, pero el camino es largo, más bien infinito. Abro la puerta de maderas magníficas, nadie se acerca a pesar de que ésta es la última oportunidad para retenerme en palacio. Pronto he de cruzar el mundo en sentido inverso a las manecillas del reloj: Recularé frente a los mesones donde Pseudo Longino solía seducir muchachas, olvidando por completo a mi escritor en ciernes favorito. Borraré mis memorias de los partidos de canchas abiertas apenas cruce el Campo de Amarte, la Tour Eiffel se transformará en una escuela sin bullicio de niños, del Sena no quedará sino un albañal expuesto, Trocadero desaparecerá cuando pase junto al puesto de frutas en ruta al parque sin fuente ni quiosco. Una señora con olor a leña verde perderá un beso y un abrazo. Joe Buck habrá huido de la miseria de New York a la de Miami. Quizás alguno de los vagabundos que toma el sol en la plaza me pregunte si cumplí la labor que el mismo Dios me asignó. Yo le responderé: "Todo caballero hace camino cuando su tarea termina. Ahora me voy en busca de Íñigo, a reposar en sus brazos de tanta correría" (Quesada, 2005, p. 340).

Explica Eribon que el gay es más libre en la medida en que se asume como tal. Así, si bien se ha dicho que no se sabe nada seguro de Germán, también es posible afirmar que su única característica incuestionable es que es un hombre que ama otros hombres. La afirmación gay, en este sentido, lo vuelve menos prisionero de la "identidad" homosexual, según lo explica Eribon: Germán, con su asunción de sí mismo, puede liberarse con la reinvención, puede "liberarse del peso de la 'identidad' que cargan quienes se esfuerzan en disimular su homosexualidad" (Eribon, 2001, p. 140). Para Germán, entonces, sacudirse del yugo de la dominación implica un auténtico esfuerzo por deshacerse de los hábitos mentales y de los discursos instituidos.

Según el trabajo de Eribon, declararse gay conlleva, necesariamente, un "desaprendizaje" y, en consecuencia, un "nuevo aprendizaje": desaprender el lenguaje del poder, con el fin de acceder a un nuevo lenguaje, a una nueva manera de hablar y a nuevos modos de "presentación de sí". Germán no solo debe aprender a hablar dos veces sino que, además, debe construir nuevas estructuras comunicativas que replanteen el orden social y sexual. Germán libera sus palabras de las trabas impuestas por el "orden" y opone su "lenguaje elegido" al "lenguaje impuesto", como opone su "identidad escogida" (una "identidad" problemática, como se ha dicho desde el inicio de este trabajo) a la "identidad asignada". La reconstrucción es, pues, crucial para entender el escape de toda estructura de opresión: Germán, con su labor sobre sí mismo, cambia toda su relación con el mundo y con los demás; asume, pues, su

20 1. tr. Hacer desaparecer por cualquier medio lo representado con tiza, tinta, lápiz, etc.; 2. tr. Hacer rayas horizontales o transversales sobre lo escrito, para que no pueda leerse o para dar a entender que no sirve; 3. tr. Desvanecer, quitar, hacer que desaparezca algo; 4. tr. Olvidar -dejar de tener en la memoria- (Real Academia Española, 2012). 
libertad, que, como afirma Nietzshe en su trabajo La gaya ciencia, consiste en no avergonzarse más de uno mismo.

\section{A manera de conclusión: el arte de la reinvención}

Porque el fuego no se conoce ni en los libros ni en los templos sino en sí mismo, en su eterno crearse y consumirse, en su unión con otras llamas y en su propagación por los bosques y las camas

Germán Germanóvich

Para un gay, afirma Eribon, nunca termina la necesidad de elegirse frente a la sociedad y a la estigmatización. Lo anterior, evidentemente, concuerda con lo dicho sobre la "identidad" gay, la cual solo puede concebirse como "un proceso nunca concluido de construcción e invención de uno mismo" (Eribon, 2001, p. 159). Germán Germanóvich evidencia lo anterior con su narración, en la que, según se ha visto, él se construye como una subjetividad que vive en la inadecuación con la "identidad asignada", con la vida familiar, con los ámbitos tan estrictamente heteronormativos de la vida laboral y, en el fondo, con todo el orden sexual que promueve los roles sociales establecidos, las identidades socialmente fijadas y aceptadas. Al respecto del estricto orden sexual, véase la siguiente cita de El gato de sí mismo:

A veces Su Majestad se enteraba de la aparición de un cadáver de muñeca, fuera por casualidad o porque el príncipe Alberto me acusaba. Entonces se ponía furioso, me gritaba cosas horribles sobre los juguetes para chiquitas y chiquitos, y yo no atinaba a decir más que esa muñequita ya no era mía sino de Dios, que se había muerto tantas semanas atrás, que por favor no gritara contra alguien que ya se había ido al cielo.... Las muñequitas también eran la causa de discusiones entre el Rey y la Reina. Ella siempre me defendía, su argumento era la curiosidad científica, la esperanza de que el Infante Germancito se convirtiera en doctor famoso, especialista en ginecobstetricia, dermatología, o en última instancia una disciplina más morbosa como la medicina forense. "No", clamaba el Rey delante de mí, "el asunto no es ése. El chiquillo va que vuela para marica [21]" (Quesada, 2005, pp. 49-50).

La familia, como institución que trabaja por instaurar y reproducir la separación entre la norma y la homosexualidad, es clara en su labor en esta novela: Germán desde su más tierna infancia aprende de su padre su propia indecibilidad y, como consecuencia, su necesidad de trabajar sobre sí mismo,

21 Explica Eribon: “'Locas', 'mariconas', 'maricas', designan realidades 'objetivas' en el mundo social y sexual, y las palabras de la estigmatización instauran y reinstauran sin cesar la 'realidad' de lo que designan, cuando parecen simplemente enunciarla o desvelarla. Llamar a alguien 'loca' o 'marica' es enunciar la 'verdad' de lo que 'es'. Pero este individuo sólo es lo que es porque las palabras (es decir, la historia colectiva del orden social y sexual sedimentada en el lenguaje y los fantasmas sociales que expresa) inscriben en su propia definición, y en su ser, toda la 'realidad' que designan, para hacer de él un ejemplar, un espécimen de una especie particular, y le atribuyen rasgos psicológicos, prácticas, sentimientos, e incluso características físicas, que quizá no sean las suyas propias, pero que encajan en la definición social y fantasmal de esa categoría de personas a la que pertenece y, por lo tanto, en la suya" (Eribon, 2004, p. 77). 
pues, como afirman los abogados de Queer Politics (citados por Eribon), "la inadecuación con la propia identidad es también la inadaptación decidida con los roles sociales y los corsés que podría instituir toda estabilización de la identidad" (Eribon, 2001, p. 164). Lo dicho, finalmente, lleva a la idea de Foucault de una "ascesis homosexual". Ya antes se indicó la importancia que, desde el proyecto literario y político de Oscar Wilde, tiene para el gay (y, en este caso, para Germán) hacer de su vida una obra de arte, una obra que le permita asumir su derecho a hablar en primera persona. La creación de sí mismo es, por lo anterior, consustancial con el trabajo literario de Germán:

Ya que la memoria traicionaba hasta su más nítida evidencia, me quedaba solamente la palabra para rescatarme y salvar mi misión en esta tierra. Corrí hacia mi aposento para sacar de la maletita de cartón el manuscrito de mis memorias y poema épico de todas las civilizaciones. Podría encontrar cierta paz en el acto de escribir, y por ende mi viaje hacia la perfección del espíritu (Quesada, 2005, p. 257).

Germán, con su narración autobiográfica, entiende su "identidad" como una construcción histórica, posible de modificar con la escritura, desde sí mismo y para sí mismo. Lo dicho, además, implica que su "identidad" está -siempre- por recrear; es decir, la construcción de la "identidad" es, para él, una tarea imposible de concluir, de ahí que, en cuanto pierde sus papeles con sus "memorias", pierde también su entusiasmo y afirma:

Temblando saqué el bulto debidamente atado, eran unas dos mil cuarenta páginas donde estaban descritas las escenas traicionadas por las fotografías. Corté los lazos con la espadita, tomé un lápiz para hacer una anotación en la página dos mil cuarenta y cuatro. La hoja encima estaba en blanco, lo cual no era extraño. La siguiente apareció igualmente sin nada escrito. La tercera tenía una mancha de humedad y olvido. Golpeé el legajo entero contra el borde de la cama, por si acaso el texto seguía dormido y necesitaba despertar. Algunas letras pálidas cayeron al edredón de plumas, unas cuantas más quedaron flotando en la tarde. A punto de sufrir un desmayo hojeé toda la obra y no había nada en ella. Toda mi historia era solamente papel en blanco. Los romances más bellos habían regresado a la voz del pueblo. Las confesiones íntimas habían sido silenciadas por el secreto. Mis proezas, mis encuentros con hombres ilustres, el dictado de Dios, todo desaparecido. Tendría que empezar de nuevo, pero sin vida suficiente para llegar al punto donde el súmmum de todos los libros había quedado la tarde anterior. "Mejor la muerte", pensé desconsolado (Quesada, 2005, p. 257).

Germán, entonces, comprueba que es imposible realizar algún día la "identidad" estable y definitiva. Para él, no hay, a lo largo de su vida, ningún tipo de reposo (ni existencial, ni social, ni psicológico); para Germán hay huida y búsqueda, como se ha concluido anteriormente.

Respecto a la necesidad que la novela de Quesada advierte en relación con los modos de ser y de pensar transmitidos por la historia o impuestos por las estructuras sociales, aquí se trata de la necesidad por la ruptura, una ruptura que libera la imaginación y que le permita al sujeto reinventarse, a partir 
de dicha huida. Esta idea de la reinvención es constante en Foucault como en Wilde; ambos autores se remitieron al "helenismo" para afirmar esta estética de sí mismo, estética que, desde el título de la novela de Quesada, se apunta. Explica Eribon, para el caso de los autores europeos:

Wilde intentaba forjar, si no una nueva "identidad", al menos un personaje, un rol, o, por decirlo en un término más moderno, una "posición" en la que fuese posible crearse a sí mismo al margen de las normas dominantes. Foucault propone inventar nuevas relaciones entre los individuos, nuevos modos de vida como medios de resistencia al poder y como agentes de una reformulación personal (Eribon, 2001, p. 340).

Con lo dicho, se puede afirmar que la novela de Quesada presenta rasgos de ambos planteamientos: Germán es un personaje que permite entender la importancia de una nueva cultura y de una nueva subjetivación, a partir de los dos vectores que Foucault explica en relación con su "estética de la existencia": una "política de la amistad" (la cual se mencionó en el apartado anterior) y una "economía de los placeres" (fundamental para explicar la importancia del homoerotismo en la literatura gay). Lo relevante, para el caso de Germán Germanóvich, consiste -finalmente- en abrir espacios de resistencia a la sujeción, pero, sobre todo, en imaginar posibilidades de reinvención de sí mismo, al margen de la norma heterosexual. Germán se dirige a Îñigo en los siguientes términos:

Simplemente dije sí, nos encontraremos de nuevo, todo será diferente, por supuesto, seremos más libres, te lo prometo, me estoy preparando para la felicidad, no te voy a extrañar porque así me lo has pedido, vos serás la dulzura que pende del aire, por vos me volveré afortunado, bello, dichoso, sabio, magnífico, generoso, inquieto, humilde... Por todo esto, cuando llegue el momento de encontrarnos no me digás nada, sólo abrazame, Íñigo, teneme un rato apretado contra tu pecho como volviéndonos uno [cursivas añadidas] (Quesada, 2001, pp. 72-73).

Germán plantea, desde la cuestión amorosa, el tema de la "subjetivación", pero también el de la "resistencia". No extraña, en este sentido, que su narrar sea un imaginar formas de "libertad" para sí y, entonces, para todos los de su "género". Germán hace hincapié en los efectos del "amor gay" sobre su "ser" y sobre su "mundo". De hecho, el amor por otro hombre cambia la vida de este personaje, lo que, además, no solo le permite formar una "bella relación" (véase la "política de la amistad" de Foucault) sino, también, le permite activar una erotización máxima de su cuerpo (lo que Foucault llama una "economía de los placeres"). Finalmente, se está acá ante una "nueva gramática del ser", que, como demuestra Germán con su labor, implica, asimismo, una novedosa forma de escribirse.

El narrador-protagonista es, entonces, un hombre impregnado por la literatura. No sorprende, pues, el constante uso de referencias literarias en su trabajo narrativo, pero estas referencias, como es claro, resultan ser parte de su reinvención, una reinvención que se podría definir como un "juego literario": 
Piensa Rasputina que una linda historia puede despertar los recuerdos dormidos del Rey. Busco y busco, pero tengo tanta amargura entre todos mis puntos cardinales que no me siento capaz, no creo que me sea posible hacer otra cosa que esperar. Entonces recuerdo que en la vieja biblioteca, junto a los manuales de carpintería y los cursos de inglés en discos, más allá de los volúmenes completos de Selecciones había una pequeña sección con obras selectas de don Marcial Lafuente Estefanía. Si yo hubiera sido escritor en lugar de poeta andante, quizás me hubiera gustado ser igual a don Marcial... Pensando que tal vez yo podría inventarme a don Marcial, Józek T. me presta su traje con corbata de pajarita, su reloj de cadena y sus anteojos sin patillas. Miro a Luis Dieciséis, el destinado a la guillotina, sonrío a medias y empiezo: "El pueblo de Truth or Consequences perdió la inocencia cuando la West Fargo decidió usarlo como escala para sus diligencias y nombrar a un nuevo sheriff [cursivas añadidas] (Quesada, 2005, pp. 202-203).

El inventar es, pues, fundamental en la narración de Germán. Inventarse (un rostro, una silueta, un personaje, un gesto, una forma de hablar o de escribirse, etcétera) no es sino una acción sobre uno mismo, que tiene como fin la transformación y, al mismo tiempo, la huida de la violencia de la "estructura estructurante" (la noción es de Pierre Bourdieu). Afirma Eribon, ya en términos más amplios:

Es inevitable comparar aquí el arte de jugar con el físico propio, de teatralizarlo para hacer de él algo nuevo y que fabrica uno mismo, por un lado a la manera en que Wilde se afanaba en moldear su apariencia, y por otro con la "teatralización" general de la afirmación de uno mismo como gay: se trata siempre de reinventar los gestos, el físico, el "ser" para la mirada ajena: todo eso que Goffman llama la "presentación de sí" (Eribon, 2001, p. 346).

Si Germán puede liberarse, es porque escoge, entonces, la huida, la cual, finalmente, no es sino lo que Eribon llama "la voluntad de encontrar "otro lugar'” (Eribon, 2001, p. 349). Huir del malestar implica para Germán toda una re-estructuración de su biografía y, por ende, de su "ser". La narración de Germán no solo es, como se puede colegir, cuestión literaria. Todo su trabajo es un movimiento hacía sí mismo que, finalmente, le permite el habla, que le devuelve la palabra ante los discursos que lo cosificaban. La obra literaria de Germán, en este sentido, se afirma en la idea de que ella no se queda en lo literario, pues, como el final mismo de la novela de Quesada lo explicita, aquí se tratan cuestiones de vida y muerte, de libertad y sufrimiento, que, claro, no se limitan necesariamente al narrador-protagonista.

La tensión que mueve la narración de Germán está, pues, ligada con lo que Foucault llama la "voluntad", pero, más aún, está ligada con su necesidad de liberarse, de buscar la vida, que no se representa sino en su "fuerza para huir". Así, el viaje por la historia de vida de este gay es el medio que se tiene acá para comprender como funcionan los sistemas de pensamiento que rigen las instituciones, para deshacer su evidencia y seguridad normativa y, como afirma Eribon, para "aflojar" los barrotes que las "tecnologías disciplinarias" han implantado en las conciencias, en las "almas" de los sujetos. 
Con lo dicho, la salida o, mejor, el escape de Germán de casa de su padre, de "palacio", de Cartago, muestra cómo el "lugar de la familia" es un lugar político, que marca al sujeto gay, ya que -como afirma Foucault sobre la "cárcel"- la casa paterna, la ciudad paterna, para Germán, es "un lugar donde se forma la historia y el tiempo surge" (Foucault citado por Eribon, 2001, p. 361): "Cartago tiene vigilantes que nunca reposan. Nunca los ves porque se han metido en las paredes. El poder maléfico de Cartago está en sus paredes, por eso y por la neblina la ciudad solamente se deja querer con amor malsano: lleno de golpes y cortaduras, de dolor y represión, de caricias y estrangulamientos" (Quesada, 2005, p. 299). Evidentemente, "Cartago" no es más que una metáfora de la subyugación, la cual -ya se ha visto antes- se talla en lo más profundo del "ser". Y es, precisamente, de este mismo "ámbito" de donde surgen, con la afirmación de sí, las "fuerzas" de las que habla Foucault: una nueva política nace de las liberaciones de Germán, de sus desplazamientos, de su escritura.

Germán escribe, por tanto, para liberar su vida -que ha estado prisionera-, escribe para "trazar líneas de huida" (la expresión es de Gilles Deleuze). La historia de este gay no es, pues, sino una historia de la "homosexualidad": ¿no plantea la biografía de este personaje una interrogación sobre la forma en la que se concibe al gay como un sujeto sometido y sobre los medios para escapar de dicha "sujeción"? La novela de Quesada, por tanto, hay que leerla como una epistemología, en la medida en que la narración "loca" de Germán no es sino un "saber distinto", y de ello se deduce toda su potencialidad.

El trabajo literario de Germán, evidentemente, aunque nace de la experiencia personal, no se queda en sí mismo; hay que repetirlo: su aprendizaje, en tanto sujeto que escribe, no solo permite su transformación sino que, asimismo, puede tener cierto valor para los demás. Esto es posible afirmarlo en la medida en que el trabajo escritural de Germán surge de un "malestar" que se comparte, un malestar experimentado con respecto a las "instituciones", como se ha visto, y que permite entender su labor literaria como una "inservidumbre voluntaria" y como una "indocilidad meditada", para usar las expresiones con las que Foucault define el pensamiento crítico.

La novela de Quesada busca, entonces, construir un discurso de resistencia que rompa no solo con la asociación del "homosexual" con "los locos", con "el disoluto", con "el libertino", con "el venéreo", con -finalmente- todos los "proscritos" (encerrados en la categoría que Foucault llama la "Sinrazón"), sino, más importante aún, que mine la "moral burguesa" instalada desde el siglo XVII. Afirma Eribon:

La moral burguesa no es, pues, solamente una moral del trabajo, sino también una moral de la familia, que determina en adelante lo que debe ser la sociedad y quién pertenece a ella de pleno derecho: "La estructura familiar, que vale a la vez como regla social y como norma de la razón... Las viejas formas del amor occidental son sustituidas por una sensibilidad nueva: la que nace de la familia y en la 
familia; excluye, como propio del orden de la sinrazón, todo lo que no es conforme a su orden o interés" (Eribon, 2001, p. 374).

La moral de la familia es, pues, el centro ideológico-discursivo que Germán busca poner en entredicho. Ya se ha afirmado antes cómo la casa paterna, en la figura de don Luis, excluye a Germán, quien no sigue el orden establecido, quien no sigue la moral de la casa Đ El Gado.

Germán huye, finalmente, del poder de control y de la vigilancia que, como su narración aclara, actúan por medio de la especificación con la que los discursos de poder lo delimitan: el acoso que sufre Germán, la caza activada por su padre, consiste en señalarlo como una "sexualidad herética" (según una expresión de Foucault) y, por tanto, en excluirlo, una exclusión que, finalmente, le hace la vida relativamente penosa:

"Tengo otra duda. No sé cómo mi padre supo mi paradero".

Leandro se ríe, avanza hacia la puerta y desde ahí se despide a gritos de Rasputina, quien no debe oír nada pues no contesta... Leandro espera hasta el último segundo para contestar mi pregunta:

"Este país es muy pequeño. No tiene suficientes esquinas para esconder a todos los fugitivos. Casi desde el mismo momento en que usted se marchó don Luis supo su paradero. Solamente fue cuestión de llamar a algunos amigos y darse una vueltecita de verificación por Santa Cruz. ¿Sabe? Cuando alguien paga se puede hacer de todo".

“¿Y por qué no me dijo nada desde el principio?", protesto con amargura en el alma y el alma en vilo".

"Porque quien pagó tampoco deseaba que usted supiera" (Quesada, 2005, pp. 188-189)".

La narración de Germán suscita, con todo lo dicho, una reflexión en torno a los poderes y a las resistencias. Según Foucault, se afronta un "mecanismo de doble impulso", de placer y poder. Y sigue: "placer de ejercer un poder que pregunta, vigila, acecha, espía, excava, palpa, saca a la luz; y del otro lado, placer que se enciende al tener que escapar de ese poder, al tener que huirlo, engañarlo o desnaturalizarlo. Poder que se deja invadir por el placer al que da caza; frente a él, placer que se afirma en el poder de mostrarse, de escandalizar o de resistir" (Foucault, 1992, p. 62). Así, a partir de esta teorización relacional del poder (que Foucault trabaja en La voluntad de saber), se puede decir que la narración de Germán organiza un "enfrentamiento" y un "reforzamiento" recíproco que, en el texto, no concluye sino con la muerte del narrador-protagonista: ¡la libertad, o la voluntad por alcanzarla, tiene un precio considerable!

Una de las formas de enfrentamiento más efectivas en la narración de este "homosexual" es, como se afirmó, su insistencia en el amor. Este tema es necesario verlo ahora a la luz de lo dicho sobre el "mecanismo de doble impulso" que explica Foucault. Así, es posible afirmar que la verdadera resistencia en 
Germán está en mostrar sus sentimientos, su vinculación con otro igual a él. Lo anterior es importante en la medida en que esta novela se aleja de lo que se podría llamar "la rebelión erótica", promovida por algunos movimientos feministas como, también, por los estudios queer. Afirma Eribon al respecto:

Huelga decir que esta concepción del "deseo homosexual" como agente de una subversión generalizada del orden social es un poco fantasiosa: para ser revolucionario no basta con traspasar las fronteras de clase o de raza en los lugares de ligue ni con practicar una sexualidad no centrada en la pareja o en la familia. Como tan certeramente dice Leo Bersani..., los mismos que practican esta sexualidad "subversiva" por la noche pueden ser racistas o fascistas durante el día o, lisa y llanamente, en calidad de dueños de una empresa o propietarios de un inmueble, comportarse como cualquier otro empresario o propietario. No hay ninguna continuidad entre la sexualidad y las posiciones políticas $y$, de haber una relación entre estos dos registros, es sin duda más compleja y no se refleja en términos de "subversión" política y social (Eribon, 2001, p. 415).

No es, evidentemente, que se esté rechazando la importancia de la "liberación sexual" en las vidas de los sujetos; por el contrario, se entiende este cambio como una renovación en la lucha por los derechos más básicos de las "minorías sexuales", lo que, para el caso de los gays y las lesbianas, no es ni más ni menos que recuperar la humanidad misma, humanidad de la que les ha despojado el sistema heteronormativo.

Siempre en relación con este cambio estratégico, se puede afirmar que el "orden de las cosas", de alguna manera, espera de los "proscritos" "actos ilegales"; es decir, la "perversión" es, de alguna forma y en cierto grado, justificada por un sistema que busca normalizar incluso las "anormalidades", a las que finalmente les da un espacio definido (en tanto no se violente "la moral" y todo se mantenga reservado a la oscuridad de la alcoba). Esta forma de "tolerancia" se puede explicar a partir de la preeminencia que la tradición judeocristiana le adjudica al "alma" en oposición al cuerpo (que se entiende como "frágil"); así, es más subversiva un "alma perdida" que un "cuerpo vicioso". La mortalidad del cuerpo, en contraposición con la infinitud vital que se le adjudica al "alma", ha hecho que se relegue al primero. De lo anterior se deduce la importancia de la posibilidad de "salvación", de "recuperación" del "alma", hasta en el último momento.

El cuerpo solo se torna significativo porque alberga el "alma", porque es su "templo". El cuerpo, entonces, soporta múltiples prohibiciones que se instauran desde ámbitos concebidos como más profundos y determinantes: desde el "alma". Esta división estratégica ha distinguido, pues, el accionar de "la norma", como un engaño que imposibilita cualquier autodesignación identitaria: se está atado en dos direcciones, se está subordinado a un sistema de impedimentos. Lo dicho debe, finalmente, permitir revalorar el "alma" y el cuerpo como "uno". Esta unidad, entonces, neutralizaría -en algún grado y de alguna manera- la estrategia que organiza las restricciones impuestas a 
los cuerpos y, entonces, a las "almas" (o, mejor, a la inversa), como entidades artificialmente establecidas, delimitadoras entre sí: el alma no es más que el cuerpo, y el cuerpo no es más que el alma.

La novela de Quesada, entonces, hace visible lo que el sistema heteronormativo realmente pretende ocultar: los "sodomitas" se aman, construyen relaciones y constituyen familias entre sí: ¡he aquí la afrenta que, desde la perspectiva de la novela, es más efectiva contra "la norma"! Manifestar el amor y la voluntad por estar junto al amado es el mejor "contraataque" frente al dispositivo de la sexualidad sobre el "cuerpo y los placeres" y no sobre "el sexo y el deseo", como afirma Foucault en La voluntad de saber. La invocación que Germán, a lo largo de su narración, hace a su amado y la mostración de sus ansias por "habitar" a Înigo debe, pues, provocar una reflexión sobre la relevancia de lo que Foucault llama el "modo de vida gay" y la "cultura gay", como "estructuras" basadas en nuevas formas de relación entre los individuos. Lo anterior se justifica en la medida en que, como explica Foucault, lo que más molesta de la "homosexualidad" a los que no son "homosexuales" es precisamente el estilo de vida gay. Afirma Eribon:

Contra Hocquenghem, contra los discursos de la liberación sexual, Foucault se propone afirmar que el agente desestabilizador del orden establecido no hay que buscarlo tanto en la "sexualización" de la sociedad, en el ligue, el sexo al aire libre, la multiplicación de compañeros, etc., como en la invención de nuevos modos de vida y nuevas formas de relación entre los individuos: "La afirmación de que ser homosexual es ser un hombre y un hombre que ama, esta búsqueda de un modo de vida choca contra esa ideología de los movimientos de liberación de los años sesenta... La homosexualidad es una ocasión de reabrir virtualidades de relación y afectivas, no tanto por las cualidades intrínsecas del homosexual, sino porque la posición que éste ocupa, 'oblicua' en cierto modo, las líneas diagonales que puede trazar en el tejido social permiten que aparezcan esas virtualidades".

En la invención de este "sistema relacional" hay que buscar la posibilidad de reinventarse y escapar a la sojuzgación que operan las normas sociales (Eribon, 2001, p. 430).

La novela de Quesada, entonces, aporta toda una reflexión política acerca de la cuestión gay; sobre todo, porque este texto patentiza la represión que sufre el gay, como un "campo múltiple de relaciones de fuerza" (Foucault, 1992, p. 135). Los poderes están en todas partes, en todos los niveles de la sociedad, pero donde haya poderes ejerciendo represión hay, asimismo, formas de resistencia, como lo demuestra la narración de Germán, cargada de formas de "desplazamientos" y de "reutilizaciones". En este sentido, el discurso amoroso de este hombre gay, al tiempo que lo afirma desde "lo profundo de su ser", es también un "discurso de rechazo":

¡Ay, Íñigo, cuánto te necesité en ese momento! [Se refiere al momento en el que el "rey" acusa a Germán y lo destierra de "Cartago"] Porque el silencio, vos sabés, tiene su modo de estar y no estar, se escurre por toda oportunidad, sigiloso avanza, te acosa, finalmente te pone a sus pies, te llena de su misma esencia, y 
entonces cómo se sufre, Íñigo, pues todo parece dicho y supuesto aunque callar haya sido la única forma de comunicación. Quizás me hubiera portado cruel con vos, porque necesitaba reclamar la distancia y tu ausencia, pero también hubiera sido tierno y sensible, pues mi crueldad hacia vos no puede durar más que la fracción más corta de tiempo. Sólo requeriría fuerzas para llenarme de valor y enfrentar sin tregua los ataques de los provocadores del reino, de los que cuchicheaban hasta falsear mis lazos afectivos. Yo merecía ser escuchado, Íñigo, pero no por las causas funestas que fabricaron los inquisidores [cursivas añadidas] (Quesada, 2005, p. 59).

Así, es posible afirmar que El gato de sí mismo es una "novela gay", en tanto contribuye a una apreciación positiva de una conciencia (la de Germán Germanóvich), que valora el afecto, el amor, el deseo y las relaciones sexuales entre hombres. Este texto plantea, con lo dicho, toda una "política gay", en la medida en que la labor de Germán puede, finalmente, definirse como una biografía colectiva, pues, según señala Foucault:

The homosexual consciousness certainly goes beyond one's individual experience and includes an awareness of being a member of a particular social group. This is an undeniable fact that dates back to ancient times. Of course, this aspect of their collective consciousness changes over time and varies from place to place (Foucault, 1983, p. 11).

Esta variabilidad permite, precisamente, la transformación y la reinvención de la que tanto se ha hablado: la sexualidad, como la "identidad", no está dada, está por crearse, ella no es un descubrimiento de un aspecto secreto del deseo, es una potencialidad que puede llevar a "nuevas formas de relaciones", "nuevas formas de amor", "nuevas formas de creación".

El gato de sí mismo, con lo dicho, demuestra cómo la vida de un ser humano está tocada por su sexualidad, la cual, para el caso de los gays, puede (debe, dice Foucault) generar modos de vida novedosos, que rechacen los modos de vida propuestos. Así, es posible afirmar que la "homosexualidad" es, para Germán y seguramente para gran parte de los gays, el agente de un cambio existencial: "hay que usar la sexualidad", afirma Foucault, para descubrir nuevas relaciones. $Y$ sigue:

Hacer el amor con alguien del mismo sexo puede entrañar naturalmente toda una serie de elecciones, toda una serie de valores distintos para los cuales no existen aún posibilidades reales. Es, pues, necesario, imaginar y crear un nuevo derecho relacional que permita que todos los tipos posibles de relaciones puedan existir sin que sean impedidos, bloqueados o anulados por instituciones relacionalmente empobrecedoras (Citado por Eribon, 2001, p. 451).

El descubrir nuevas relaciones es, precisamente, el centro de la búsqueda del narrador-protagonista de esta novela, de ahí, también, que se pueda entender como un sujeto en devenir, un sujeto en excursión: Germán se busca a sí mismo para, finalmente, encontrarse con otros iguales a él, representados en la figura de su amado Íñigo. Esta característica que ahora se entiende para 
el caso del "sujeto" gay de esta novela permite, pues, reafirmarlo como "fuerza creadora". Antes se afirmó que la "identidad" gay es una "identidad irrealizable", pero esta imposibilidad no es otra cosa que un trabajo constante de decisión sobre el propio "ser", es una forma de resaltar al gay en su potencialidad creadora, según lo explica Foucault. Lo dicho explica la celebración de la (auto) inventiva que se le ha señalado a Germán: la resistencia de este personaje está en su experimentación estratégica, en su coherencia estratégica, en su poder imaginativo, un poder que no se queda en la nada sino que constituye una recuperación del "ser".

La novela de Quesada, finalmente, presenta la experiencia personal de Germán, su biografía, como un foco de inspiración teórica y política. ¿No es este trabajo consecuencia de El gato de sí mismo? ¿No está este investigador leyendo su experiencia en la experiencia de Germán Germanóvich y, a partir de ello, reflexionando sobre la cuestión gay? Lo que está en juego en la novela de Quesada es, como afirma Eribon para el caso de la producción de Foucault:

La existencia de los individuos moldeados por la historia de la homosexualidad completa, una historia del sojuzgamiento, pero también de la resistencia y de esa pulsión heterotópica que condujo a los gays a inventar "modos de vida" distintos, improbables, inéditos. $\mathrm{O}$, en cualquier caso, a plantearse continuamente la cuestión de inventarlos (Eribon, 2001, p. 468).

\section{Referencias}

Althusser, Louis. (1977). Ideología y aparatos ideológicos del Estado. Freud y Lacan. Buenos Aires: Nueva Visión.

Amoretti, María. (2003). Sociocriticismo: Institucionalidad e historia de un cuerpo teórico en formación. Filología y Lingüística, XXIX(1), 7-30.

Butler, Judith. (2001). El género en disputa: el feminismo y la subversión de la identidad. México: Paidós.

Bourdieu, Pierre. (1999). La miseria del mundo. Argentina: Fondo de Cultura Económica.

Eribon, Didier. (2001). Reflexiones sobre la cuestión gay. Barcelona: Anagrama.

Eribon, Didier. (2004). Una moral de lo minoritario: Variaciones sobre un tema de Jean Genet. Barcelona: Anagrama.

Foucault, Michel. (Otoño, 1982 / Invierno, 1983). Sexual Choice, Sexual Act: An Interview with Michel Foucault. Salmagundi, (58/59).

Kosofsky Segdwick, Eve. (1998). Epistemología del armario. Barcelona: Ediciones de la Tempestad. 
Nietzsche, Friedrich. (2000). El gay saber o La gaya ciencia. Madrid: Espasa Calpe.

Quesada, Uriel. (1985). Ese día de los temblores. San José: Editorial Costa Rica.

Quesada, Uriel. (1990). El atardecer de los niños. San José: Editorial Costa Rica.

Quesada, Uriel. (1996). Larga vida al deseo. San José: Editorial de la Universidad Estatal a Distancia.

Quesada, Uriel. (1999). Si trina la canaria. Cartago: Editorial Cultural Cartaginesa.

Quesada, Uriel. (2004). Lejos, tan lejos. San José: Editorial Costa Rica.

Quesada, Uriel. (2004). El escritor y la experiencia del clóset. Ponencia leída el 6 de mayo en Casa de América, Madrid.

Quesada, Uriel. (2005). El gato de sí mismo. San José: Editorial de Costa Rica.

Quesada, Uriel. (2008). Viajero que huye. San José: Editorial Uruk.

Real Academia Española. (2012). Diccionario de la Real Academia Española (décimo segunda edición). Recuperado de: http://lema.rae.es/drae/

Rojas González, José Pablo. (2012). El gato de sí mismo, de Uriel Quesada: Novela de la travestización literaria (tesis de Maestría en Literatura Latinoamericana). Universidad de Costa Rica, San José, Costa Rica.

Ross, Lauren A. (2010). Camp it up: Camp in the portrait photography of Daniela Rossell and Pierre et Gilles (tesis de Maestría). Universidad de San Diego, California. 